\title{
Diversity of Odonata (Insecta) in Seasonal Deciduous Forest fragments in southern Brazil (state of Rio Grande do Sul), with a new record for the state and comments on the seasonal distribution of the species
}

\author{
Mateus Marques Pires ${ }^{1 *}$ ¿ Carla Bender Kotzian², Cleber Sganzerla ${ }^{3}$, Gabriel Prass ${ }^{3}$, \\ Marina Schmidt Dalzochio ${ }^{3}$ \& Eduardo Périco Ed $^{3}$ \\ ${ }^{1}$ Universidade do Vale do Rio dos Sinos, Laboratório de Ecologia e Conservação de Ecossistemas Aquáticos, \\ Av. Unisinos, 950, 93022-750, São Leopoldo, RS, Brasil \\ ${ }^{2}$ Universidade Federal de Santa Maria, Programa de Pós-Graduação em Biodiversidade Animal, Av. Roraima, \\ 1000, 97105-900, Santa Maria, RS, Brasil \\ ${ }^{3}$ Universidade Vale do Taquari, Laboratório de Ecologia e Evolução, Av. Avelino Tallini, 171, 95914-014, \\ Lajeado, RS, Brasil \\ *Corresponding author: Mateus Marques Pires, e-mail: marquespiresm@gmail.com
}

PIRES, M. M., KOTZIAN, C. B., DALZOCHIO, M. S., SGANZERLA, C., PRASS, G., PÉRICO, E. Diversity of Odonata (Insecta) in Seasonal Deciduous Forest fragments in southern Brazil (state of Rio Grande do Sul), with a new record for the state and comments on the seasonal distribution of the species. Biota Neotropica. 19(4): e20190769. http://dx.doi.org/10.1590/1676-0611-BN-2019-0769

\begin{abstract}
We present an Odonata (Insecta) check list of species occurring in a fragment of the Seasonal Deciduous Forest (Atlantic Forest biome) from the central region of the state of Rio Grande do Sul (RS), southern Brazil, along with a list of the odonate species recorded in this phytoecological region for the state. In addition, we provide comments on the seasonal distribution of the species occurring in the study area. Two streams and seven farm ponds located in the middle course of the Jacuí River basin were surveyed between December 2007 and February 2009. Overall, we recorded 49 species from 21 genera and six families. Argia serva Hagen in Selys, 1865 (Coenagrionidade) had its first occurrence record mentioned for the state, elevating to 183 the total number of Odonata species occurring in Rio Grande do Sul. The number of species recorded in the study area corresponds to $\sim 26 \%$ of the known Odonata diversity in RS. Libellulidae was the most species-rich family ( 22 species, $\sim 45 \%$ of the total), followed by Coenagrionidae (18 species, $37 \%$ of the total). The checklist for the Seasonal Deciduous Forest in RS indicated the occurrence of 83 species of Odonata in this phytoecological region ( $45 \%$ of the known odonate species in the state). This elevated diversity could be related to the density of the vegetation structure. In the study area, 20 species were found in streams, and 45 in farm ponds. Species occurrence showed marked seasonal patterns in the study area, with $88 \%$ of the species recorded from summer to autumn, and no species detected in streams in the winter. Moreover, $70 \%$ of the species were recorded in either one or two seasons in farm ponds, while $65 \%$ occurred solely in one season in streams. This result indicates that the life cycle of Odonata in southern Brazil is strongly influenced by seasonal patterns in temperature.
\end{abstract}

Keywords: dragonflies, inventory, Atlantic Forest, streams, farm ponds.

\section{Diversidade de Odonata (Insecta) em fragmentos de Floresta Estacional Decidual no Sul do Brasil (estado do Rio Grande do Sul), com um novo registro para o estado e comentários sobre a distribuição sazonal das espécies}

\footnotetext{
Resumo: Uma checklist das espécies de Odonata (Insecta) de um fragmento de Floresta Estacional Decidual (Bioma Mata Atlântica) localizado na região central do estado do Rio Grande do Sul (RS) é apresentada neste estudo, bem como uma checklist das espécies para esta região fitoecológica para o estado. Além disso, também é discutida a distribuição temporal da ocorrência das espécies na área de estudo. Dois riachos e sete reservatórios localizados no trecho médio da bacia do rio Jacuí foram estudados entre dezembro de 2007 e fevereiro de 2009. Ao todo, 49 espécies de 21 gêneros e seis famílias foram registradas. Argia serva Hagen in Selys, 1865 (Coenagrionidade) teve seu primeiro registro mencionado para o estado, elevando para 183 o número total de espécies de Odonata
} 
Pires, M.M. et al.

ocorrentes no Rio Grande do Sul. O número de espécies registrado na área de estudo corresponde a cerca de $26 \%$ da diversidade de Odonata conhecida no RS. Libellulidae foi a família mais rica (22 espécies, $45 \%$ do total), seguida por Coenagrionidae (18 espécies, $37 \%$ do total). A lista compilada de espécies para a Floresta Estacional Decidual no RS indicou a ocorrência de 83 espécies de Odonata nesta região fitoecológica ( $45 \%$ da diversidade de Odonata conhecida do estado). Essa alta diversidade pode estar relacionada à densidade da estrutura da vegetação. Na área de estudo, 20 espécies foram encontradas em riachos e 45 em reservatórios. A distribuição temporal das espécies foi marcadamente sazonal na área de estudo, com $88 \%$ das espécies registradas do verão ao outono, e nenhuma espécie detectada em riachos no inverno. Além disso, 70\% das espécies ocorreram em uma ou duas estações em reservatórios, enquanto $65 \%$ das espécies registradas em riachos foram detectadas somente em uma estação. Este resultado indica que o ciclo de vida das espécies de Odonata no extremo sul do Brasil é fortemente influenciado pelos padrões sazonais de temperatura.

Palavras-chave: libélulas, inventário, Mata Atlântica, riachos, reservatórios.

\section{Introduction}

Odonata (dragonflies and damselflies) is a small order of aquatic insects with high importance to the ecological dynamics of freshwater ecosystems (Corbet 2004). Over 6300 species of the order are described worldwide (Schorr \& Paulson 2019). The Neotropical Region holds an important portion of the global diversity of Odonata, with over 1700 resident species (von Ellenrieder 2009). However, in Brazil, the largest country of the region (covering $\sim 50 \%$ of the area of South America), only 860 species from 15 families and 146 genera have been recorded to date (Pinto 2019). An extensive review on the diversity of Odonata in Brazil conducted in the early 2000s (De Marco \& Vianna 2005 ) showed that studies had a remarkably uneven distribution in the country, with only $\sim 1 / 3$ of the territory adequately surveyed. Many studies have been carried out since then, and although the knowledge on the diversity of Odonata increased in few regions (Nóbrega \& De Marco 2011, Juen \& de Marco 2012, Koroiva et al. 2017, Dalzochio et al. 2018), no significant changes occurred in the original scenario. Thus, the knowledge of the spatial distribution of Odonata in Brazil remains poorly understood.

In the state of Rio Grande do Sul (RS; area of $\sim 282000 \mathrm{~km}^{2}$ ), southernmost Brazil, many inventories and studies on the distribution of Odonata have been recently conducted (Renner et al. 2015, Renner et al. 2016a, b, Renner et al. 2017, Dalzochio et al. 2018). A recent compilation of the studies conducted in the state mentioned the occurrence of 182 species from nine families and 57 genera (Dalzochio et al. 2018), representing $\sim 21 \%$ of the known diversity of Odonata in Brazil (Pinto 2019). Nevertheless, as in the rest of the Brazilian territory, many areas of the state remain poorly investigated (Dalzochio et al. 2018). The southernmost boundaries of the Atlantic Forest biome originally covered $\sim 37 \%$ of the territory of RS (IBGE 2004). Although the Atlantic Forest is considered a hotspot of biodiversity in the Neotropical Region (Mittermeier et al. 2011), nowadays the remnants of this biome in RS are reduced to less than $10 \%$ of the original area (Rio Grande do Sul 2019). Previous studies described that Atlantic Forest remnants in Southern Brazil hold a great diversity of various insect groups (Ferro \& Teston 2009, Iserhard et al. 2017). However, inventories of aquatic insects in the Atlantic Forest in RS are scarce, and, particularly for Odonata, large areas of the biome remain underrepresented regarding the knowledge of Odonata composition (Dalzochio et al. 2018).
The Atlantic Forest comprises several vegetation types (phytoecological regions) in the state of Rio Grande do Sul, ranging from Seasonal and Ombrophilous forests to highland grasslands matrices with patches of Araucaria forests (Oliveira-Filho \& Fontes 2000, Cordeiro \& Hasenack 2009, IBGE 2012) (Figure S1). Most inventories of Odonata conducted in the Atlantic Forest from RS have so far focused regions of the Highland Grasslands (Campos de Cima da Serra) (Kittel \& Engels 2014, 2016, Renner et al. 2016a, b), while in the Seasonal Deciduous Forest phytoecological region, most of the current knowledge stem from inventories limited to a single basin (Consatti et al. 2014, Renner et al. 2015, Hanauer \& Renner 2008, Renner et al. 2013) and sparse species occurrence records (see references in Dalzochio et al. 2018). Thus, the species composition of Odonata in this phytoecological region remains as one of the least studied in RS (Dalzochio et al. 2018). Furthermore, landscape structure features such as vegetation types are an important regional driver of the spatial distribution of Odonata (Paulson 2006, Kadoya et al. 2008). Phytoecological regions were found to play an important role in structuring the composition of many insect groups in RS (Ferro \& Teston 2009, Siewert et al. 2014), and a recent study carried out in RS showed that the composition of Odonata largely changed among different vegetation types in the Pampa biome (Renner et al. 2019). However, no assessment of the differences in the composition of Odonata among the vegetation types of the Atlantic Forest biome in RS has been conducted yet.

Data on the biology of odonate species are also scarce in the subtropical regions of Brazil, greatly hindering the understanding of the patterns of diversity of the order. For instance, studies focusing on the life cycle and the temporal distribution of species of Odonata are rather incipient in southern Brazil. Previous studies have showed that several factors influence the life history of odonates, and climate is a strong driver of their life cycles (Corbet 2004). This is because seasonal environmental factors such as patterns in photoperiod, rainfall and temperature influence larval development and the activity patterns of adults, thus affecting the number of generations produced by odonate species across different climatic regions (Corbet 2004, Corbet et al. 2006). Data from tropical regions in Brazil showed that the life cycle of many odonates is linked to the wet-dry season (Vilela et al. 2016). However, while most of the Brazilian territory has tropical climate, the predominant climates in RS range from subtropical to subtemperate 
(Maluf 2000), i.e., they are characterized by the absence of a dry season, but show remarkable cold winters and regularly distributed rainfall. It should therefore be expected that odonate species in RS have marked differences in their life cycles in relation to species inhabiting tropical regions from Brazil.

Habitat types (e.g., lentic and lotic) hold distinct compositions of odonate species (Renner et al. 2018). In addition, habitat type can influence the life cycle of odonate species. The review by Corbet et al. (2006) showed that important life-history traits of Odonata such as the length of the larval period and number of annual generations (voltinism) greatly changed between species from lentic and lotic ecosystems, likely due to the different ecological dynamics among habitat types, which in turn can influence certain traits related to larval growth in odonates (Córdoba-Aguilar 2008). However, studies assessing the life cycles and the seasonal distribution of Odonata in distinct habitat types are missing in southern Brazil.

In this context, we provided in this study a checklist of the species of Odonata occurring in a fragment of the Seasonal Deciduous Forest of the Atlantic Forest biome from southernmost Brazil (state of Rio Grande do Sul). We also compiled a checklist of Odonata species occurring in the Seasonal Deciduous Forest from Rio Grande do Sul, with comments on the diversity of Odonata in phytoecological regions in the state. Finally, we provided further information on the life cycle of the species inhabiting streams and farm ponds. In particular, we investigated seasonal patterns of species occurrence in the study area, in order to improve the knowledge of odonate biology in southern Brazil.

\section{Material and Methods}

\section{Study area}

This study was conducted in the municipalities of Agudo and Ibarama (53 $\left.3^{\circ} 10^{\prime} \mathrm{W} ; 29^{\circ} 10^{\prime} \mathrm{S}\right)$, central region of the state of Rio Grande do Sul (RS). The study area corresponds to the drainage area of the middle course of the Jacuí River basin (Figure 1), one of the most important watersheds of RS ( $\sim 800 \mathrm{~km}$ long and area of $\left.\sim 71,000 \mathrm{~km}^{2}\right)$ (Zamanillo et al. 1989). The Jacuí River basin runs along the transition between the Southern Brazilian Plateau (Planalto Meridional Brasileiro) and the Central Depression (Depressão Central) of RS, with altitudes ranging from 50 to $500 \mathrm{~m}$ (Pereira et al. 1989). The original vegetation in the study area is the Seasonal Deciduous Forest, in the southernmost boundaries of the Atlantic Forest biome (Durlo et al. 1982, Marcuzzo et al. 1998). Currently, few forest remnants and secondary-growth fragments distributed among small rural properties characterize the land use in the region (Rio Grande do Sul 2019), mostly because declivity hinders the practice of large agricultural activities (Marcuzzo et al. 1998). Nonetheless, the study area holds a large portion of the remnants of Seasonal Deciduous Forest in RS (Cordeiro \& Hasenack 2009). The climate in the region is Cfa of Köppen, with average annual temperature ranging from 18 to $22{ }^{\circ} \mathrm{C}$, while in winter periods the temperature is generally lower than $10^{\circ} \mathrm{C}$ (Maluf 2000). Rainfall is regularly distributed throughout the year, with the annual precipitation ranging from 1500 to $1750 \mathrm{~mm}$ (Pereira et al. 1989).

\section{Data collection}

Qualitative surveys of adult odonates were carried out monthly (from March 2008 to February 2009) at six sampling sites in the study area (four farm ponds and two streams contributors of the Jacuí River; Figure 1). The specimens were collected with a hand net in sunny days between 9:00 AM and 16:00 PM, periods of the day matching with the peak of activity of adults. Collection teams ranged from two to three persons, totaling a sampling effort of 1 hour by person. Collections were carried out along the margins of the farm ponds and stretches of $\sim 50 \mathrm{~m}$ in the streams. All sites were previously assessed in studies focusing on the diversity and temporal distribution of larval assemblages of Odonata (Pires et al. 2013, 2014). The detailed description of the environment and the monthly-sampled data for each stream and farm pond studied are also available in the previously cited references. For the general inventory, records from surveys conducted between December 2007 and April 2008 in three additional farm ponds were also included in the study, adding up to nine sampling sites (Table 1; Figure 1). The collected specimens were fixed in situ with ethanol $70 \%$. In the laboratory, specimens were determined to species level according to specialized literature (Garrison et al. 2006, Lencioni 2005, 2006). All the collected specimens were preserved in $85 \%$ ethanol and archived in the collection of the Science Museum (MCN) of the Vale do Taquari University (UNIVATES, Lajeado, Rio Grande do Sul, Brazil; collection ID from 2160 to 2371).

\section{Data analyses and data compilation}

We assessed the species richness in the study area according to the following methods: we first computed species accumulation curves for each habitat type (farm ponds and streams). The mean curve was generated after 500 random permutations of the samples (Gotelli \& Colwell 2001). We also estimated the extrapolated richness in each habitat type using two incidence-based non-parametric richness estimators: first- and second-order Jackknife. Species accumulation curves and richness estimators were respectively calculated with the functions specaccum and specpool from the vegan package (Oksanen et al. 2018) in the R statistical environment (R Core Team 2018). The analyses of species richness were restricted to the subsets of the farm ponds and streams that were monthly sampled (from March 2008 to February 2009; streams: $\mathrm{N}=24$; farm ponds: $\mathrm{N}=48$ ).

In order to investigate and estimate the life cycles of species of Odonata in the study area, we took into consideration the observed number of collections of adult specimens along monthly date ranges broadly corresponding to the austral seasons: fall (March 2008 - May 2008); winter (June 2008 - August 2008); spring (September 2008 November 2008), summer (December 2008 - February 2009). We thus used a combination of the number of observations and the consecutive occurrence of each odonate species as proxies of the number of generations produced within the sampling period and as primary sources for the estimations of the life cycles of each species. In this sense, species detected solely in one season were considered univoltine (i.e., species that likely had only one generation), while species collected over two or more consecutive seasons were considered bi- or multivoltine (i.e., species with two or more generations within a year). 


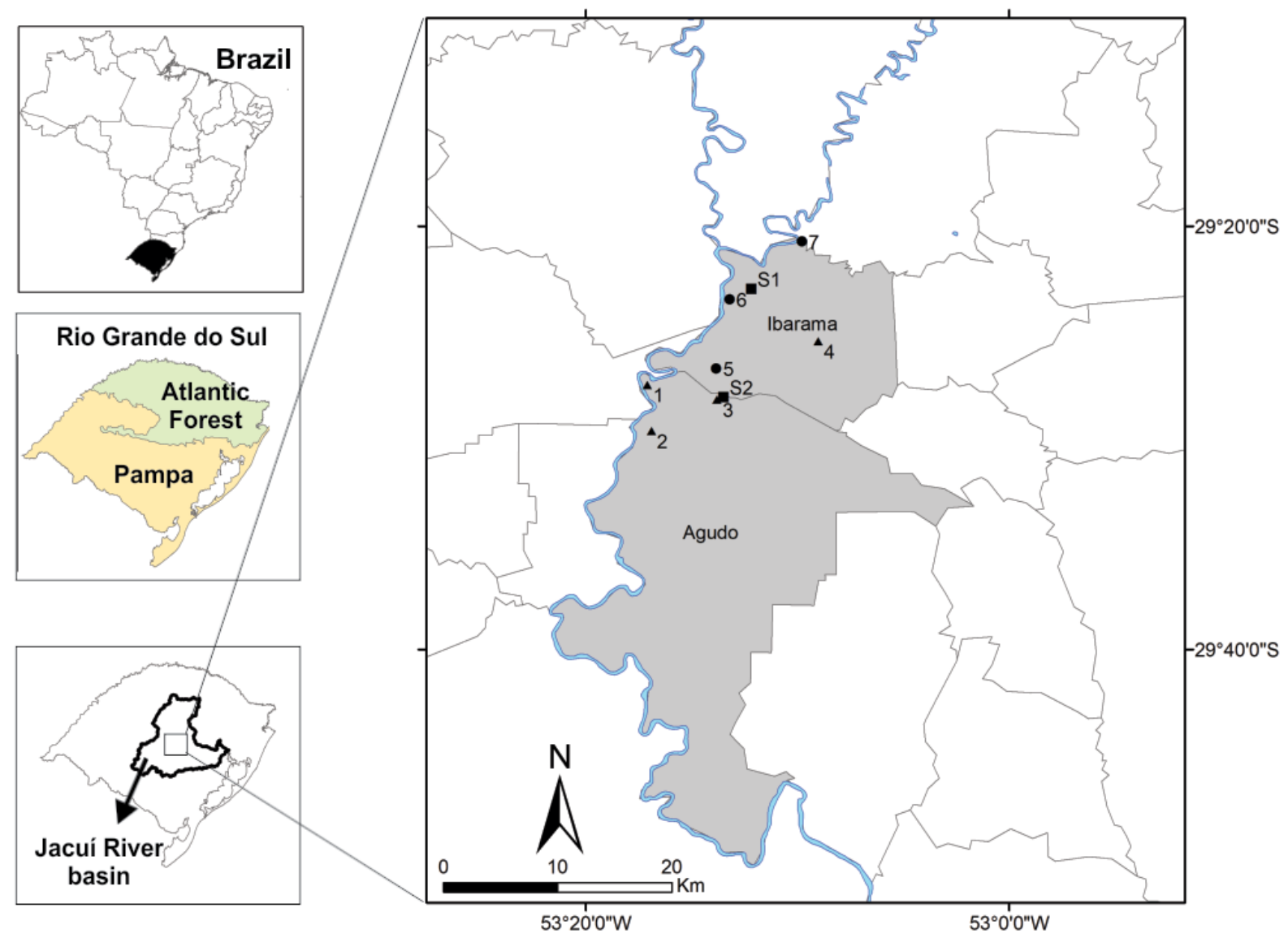

Figure 1. Map of the study area indicating the location of the state of Rio Grande do Sul and the Jacuí River basin drainage area. At the right, the blue line represents the main course of the Jacuí River and the municipalities covered in the study (grey). Triangles $(1-4)$ : monthly-sampled farm ponds. Squares (S1 and S2): monthly-sampled streams (from March 2008 to February 2009). Circles (5 - 7): additional farm ponds sampled between December 2007 and January 2008.

Table 1. Geographic coordinates of the sampling sites. S1 and S2, see Figure 1.

\begin{tabular}{|c|c|}
\hline \multicolumn{2}{|c|}{ Sites sampled from March 2008 to February 2009} \\
\hline Site & Coordinates \\
\hline Lajeado da Gringa Stream (S1) & $29^{\circ} 22^{\prime} 58 \mathrm{~S} 53^{\circ} 12^{\prime} 11 \mathrm{~W}$ \\
\hline Lajeado do Gringo Stream (S2) & $29^{\circ} 28^{\prime} 05 \mathrm{~S} 53^{\circ} 13^{\prime} 30 \mathrm{~W}$ \\
\hline Farm Pond 1 & $29^{\circ} 27^{\prime} 30 \mathrm{~S} 53^{\circ} 17^{\prime} 30 \mathrm{~W}$ \\
\hline Farm Pond 2 & $29^{\circ} 29^{\prime} 41 \mathrm{~S} 53^{\circ} 16^{\prime} 54 \mathrm{~W}$ \\
\hline Farm Pond 3 & 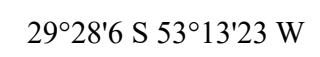 \\
\hline Farm Pond 4 & $29^{\circ} 25^{\prime} 27 \mathrm{~S} 53^{\circ} 9^{\prime} 1 \mathrm{~W}$ \\
\hline \multicolumn{2}{|c|}{ Sites sampled between December 2007 and April 2008} \\
\hline Farm Pond 5 & $29^{\circ} 26^{\prime} 44 \mathrm{~S} 53^{\circ} 16^{\prime} 50 \mathrm{~W}$ \\
\hline Farm Pond 6 & $29^{\circ} 23^{\prime} 28 \mathrm{~S} 53^{\circ} 13^{\prime} 54 \mathrm{~W}$ \\
\hline Farm Pond 7 & $29^{\circ} 20^{\prime} 12 \mathrm{~S} 53^{\circ} 14^{\prime} 02 \mathrm{~W}$ \\
\hline
\end{tabular}

Finally, we compiled the occurrence records of species of Odonata within the Seasonal Deciduous Forest phytoecological region from the Atlantic Forest biome in RS. For this purpose, we interpolated the occurrence records of Odonata in RS from Dalzochio et al. (2018) with the original area of the Seasonal Deciduous Forest in the state (IBGE 2012) (Figure S1). We further compared the number of species recorded in the Seasonal Deciduous Forest with the other phytoecological regions from the Atlantic Forest in RS (including the number of exclusive and shared species among regions). In view of the restricted number of occurrences in the other phytoecological regions, in this step we restricted the comparison to the Highland Grasslands.

\section{Results}

We collected 626 specimens from six families, 21 genera and 49 species (including 32 specimens assigned to genus level only) in the study area. However, the species accumulation curve for all samples combined $(\mathrm{N}=76)$ did not reach the asymptote (Figure 2a), suggesting that it would increase with additional effort. The extrapolated richness calculated by each richness estimator ranged from 65.77 (first-order Jackknife; standard error $=4.94$ ) to 73.68 (second-order Jackknife). Libellulidae was the most species-rich family (22 species from ten genera; $44.8 \%$ of the total), followed by Coenagrionidae (18 species from six genera; $36.5 \%$ of the total). The most species-rich genera were Acanthagrion Selys, 1876 (Coenagrionidae), Lestes Leach, 1815 (Lestidae) and Micrathyria Kirby, 1889 (Libellulidae) (five species each), followed by Oxyagrion Selys, 1876 (Coenagrionidae) and Erythrodiplax Brauer, 1868 (Libellulidae) (four species each) (Table 2). 

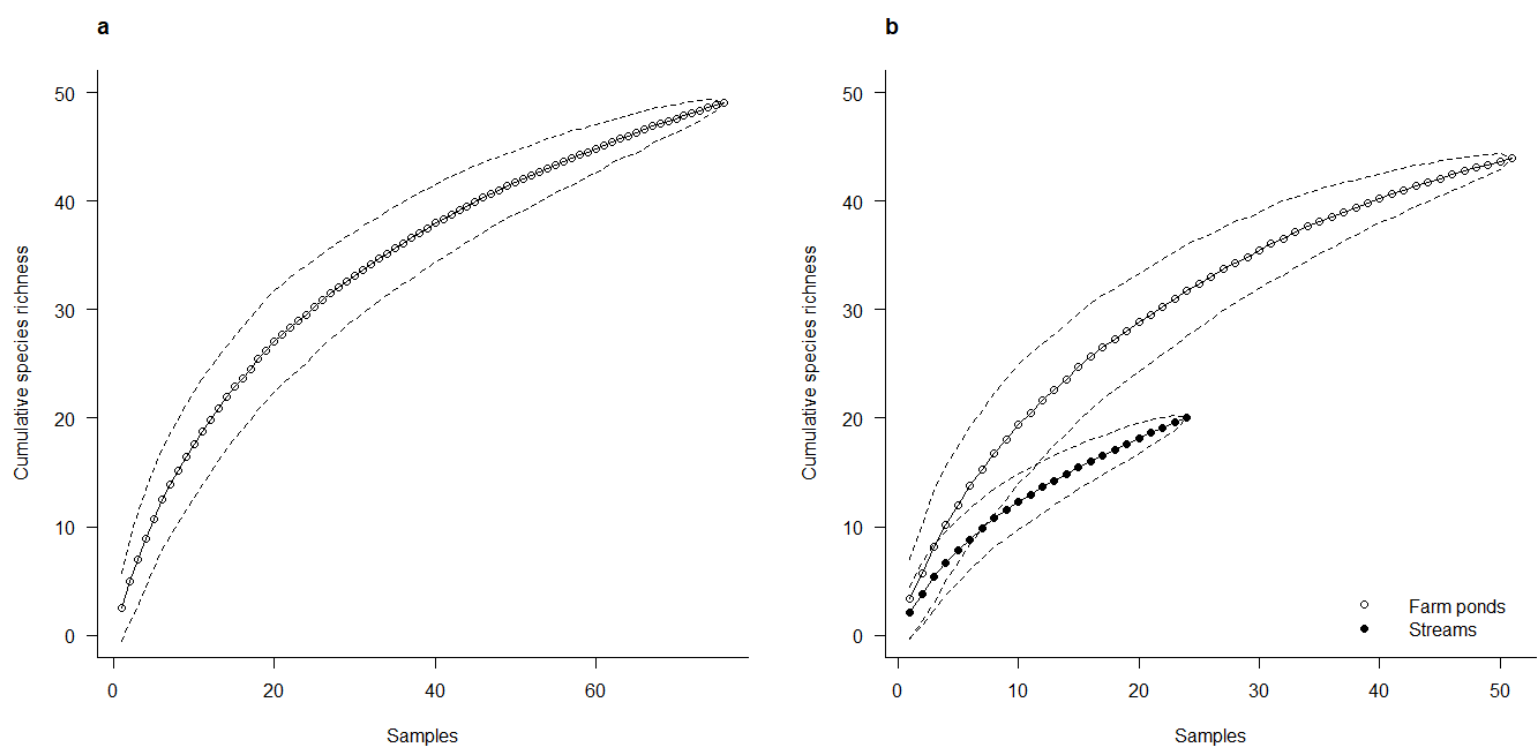

Figure 2. Cumulative richness of species of Odonata in the middle course of the Jacuí River basin. (a) curve generated for the entire data set ( $\mathrm{N}=76$ samplings). (b) curves based on the subsets of the species recorded in streams and farm ponds.

The richness and composition recorded in the study area differed between streams and farm ponds (Table 2). Twenty species occurred in streams, while 45 species occurred in farm ponds. In addition, species accumulation curves did not stabilize according to habitat type (Figure 2b). In streams, the extrapolated richness calculated by richness estimators ranged from 30.54 (standard error $=3.98$; first-order Jackknife) to 37.99 (second-order Jackknife), while in farm ponds, it ranged from 58.7 (standard error $=4.92$; first-order Jackknife) to 64.64 (second-order Jackknife). In other words, the richness of Odonata should be higher not only in the study area as a whole, but also in each habitat type.

In relation to the seasonal occurrence of the species in the study area, $88 \%$ of the species $(\mathrm{N}=40)$ were observed between the spring and autumn. In the winter, no species were detected in streams, whereas only five species (Acanthagrion cuyabae Calvert, 1909, Acanthagrion gracile (Rambur, 1842), Homeoura chelifera (Selys, 1876), Ischnura sp. and Lestes pictus Hagen in Selys, 1862) were detected in farm ponds (Table 3). In farm ponds, the season with the highest number of observed species was summer $(\mathrm{N}=28 ; 70 \%)$, followed by autumn ( $\mathrm{N}$ $=24 ; 60 \%)$. In streams, autumn was the season with the highest number of species $(\mathrm{N}=13 ; 65 \%)$, followed by spring $(\mathrm{N}=11 ; 55 \%)$. The most frequent species in this environment were Argia albistigma Hagen in Selys, 1865, Brechmorhoga nubecula (Rambur, 1842) and Hetaerina rosea Selys, 1853. They occurred in all seasons except winter (Table 3 ).

The compilation of species records of Odonata showed that 83 species from 39 genera and seven families occur in the Seasonal Deciduous Forest remnants of RS (including the species recorded in this study; Table S1). Furthermore, a comparison of the species composition registered in the Seasonal Deciduous Forest with the studies conducted in the Highland Grasslands from RS (Kittel \& Engels 2014, 2016; Renner et al. 2015, 2016a, b and references within Dalzochio et al. 2018) showed that 48 species were exclusive of the Seasonal Deciduous Forest, while 35 species were shared with the Highland Grasslands (Table S1).

\section{Discussion}

\section{Diversity of Odonata in the study area}

The number of species recorded in the study area corresponds to $\sim 26 \%$ of the species of Odonata mentioned up to the moment to RS (Dalzochio et al. 2018). This result indicates that the study area can harbor approximately one-third of the known diversity in RS. The richness observed in the study area was lower than that registered in inventories conducted in tropical Brazilian regions (Anjos-Santos \& Costa 2006, Souza et al. 2013, Koroiva et al. 2017; 77, 57 and 111 species, respectively). This pattern was also valid after taking into account the habitat types assessed. The richness here observed for streams was lower than that observed for other streams in Brazil (Assis et al. 2005, Ferreira-Peruquetti \& Fonseca-Gessner 2010, Juen et al. 2014; 29, 27 and 79 species, respectively). In relation to lentic habitats, (De Marco et al. 2014) detected 56 species in ponds from central Brazil (Cerrado biome). However, taking into account that our results stem from samplings conducted in just nine sites, the richness recorded here could be higher. In this sense, the inventory of odonate larvae previously conducted by Pires et al. (2013) revealed the occurrence of 30 genera in the study area, suggesting the existence of a higher diversity.

The diversity pattern of odonate families here observed was analogous to previous studies. The higher diversity of Libellulidae and Coenagrionidae (which added up to almost $80 \%$ of the species in the study area) was also detected in southeastern and central Brazil (Souza et al. 2013; Vilela et al. 2016; Koroiva et al. 2017; Barbosa et al. 2019; Borges et al. 2019) as well as in other studies conducted in Rio Grande do Sul (Pires et al. 2013; Renner et al. 2016a, b). These results corroborate the findings that Libellulidae and Coenagrionidae are the most speciose families of Odonata in the Neotropical Region (Kalkman et al. 2008). 
Pires, M.M. et al.

Table 2. Composition of species of Odonata recorded in the study area according to habitat type.

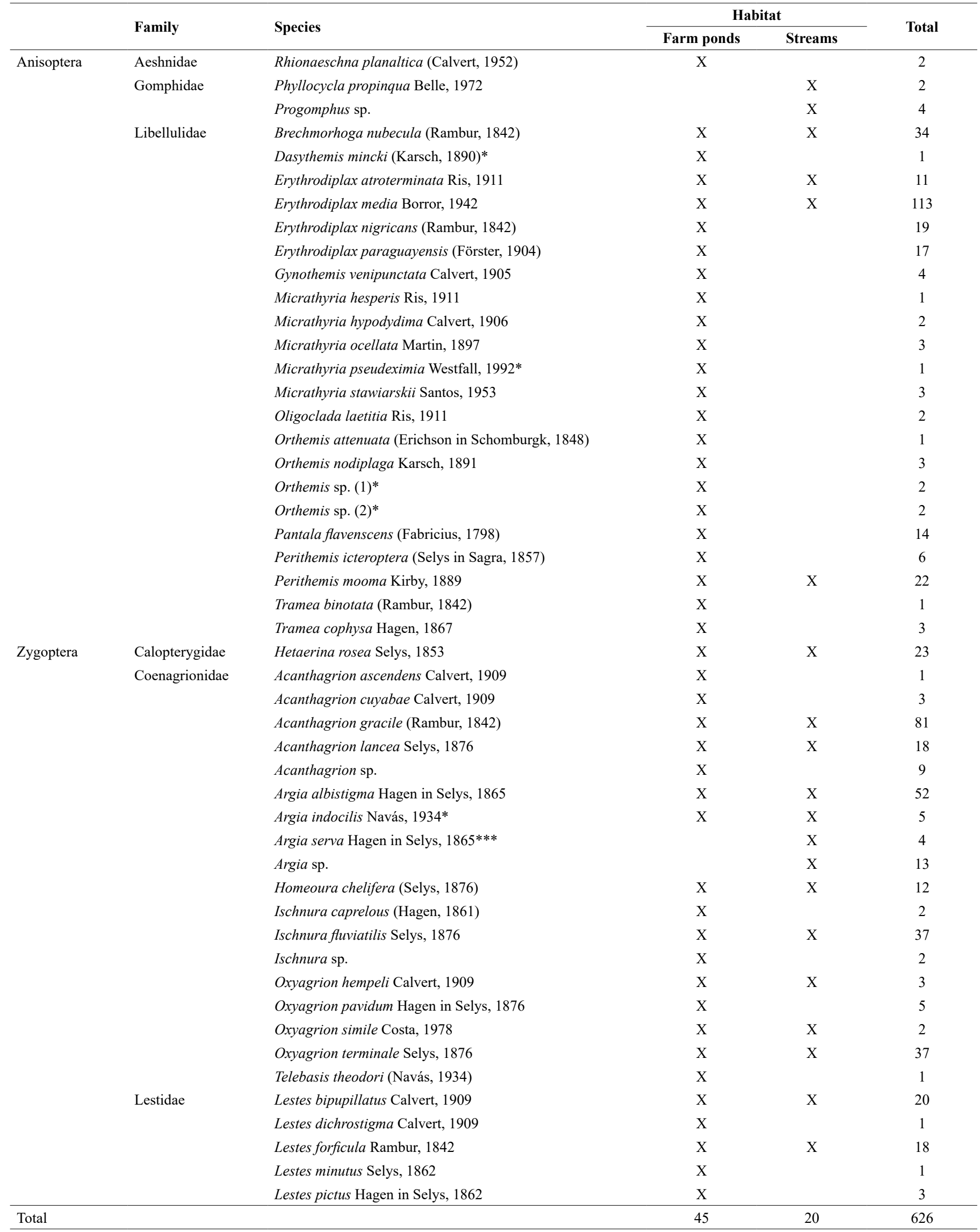

* = species recorded in the additional farm ponds between December 2007 and April 2008. *** = first record for the state of Rio Grande do Sul. 
Odonata in the Seasonal Deciduous Forest from RS

Table 3. Occurrence of odonate species in the study area according to seasons and habitat type. Data refer to the monthly samplings conducted between March 2008 and February 2009. A = autumn (March 2008 - May 2008); W = winter (June 2008 - August 2008); Sp = spring (September 2008 - November 2008); Sm = summer (December 2008 - February 2009).

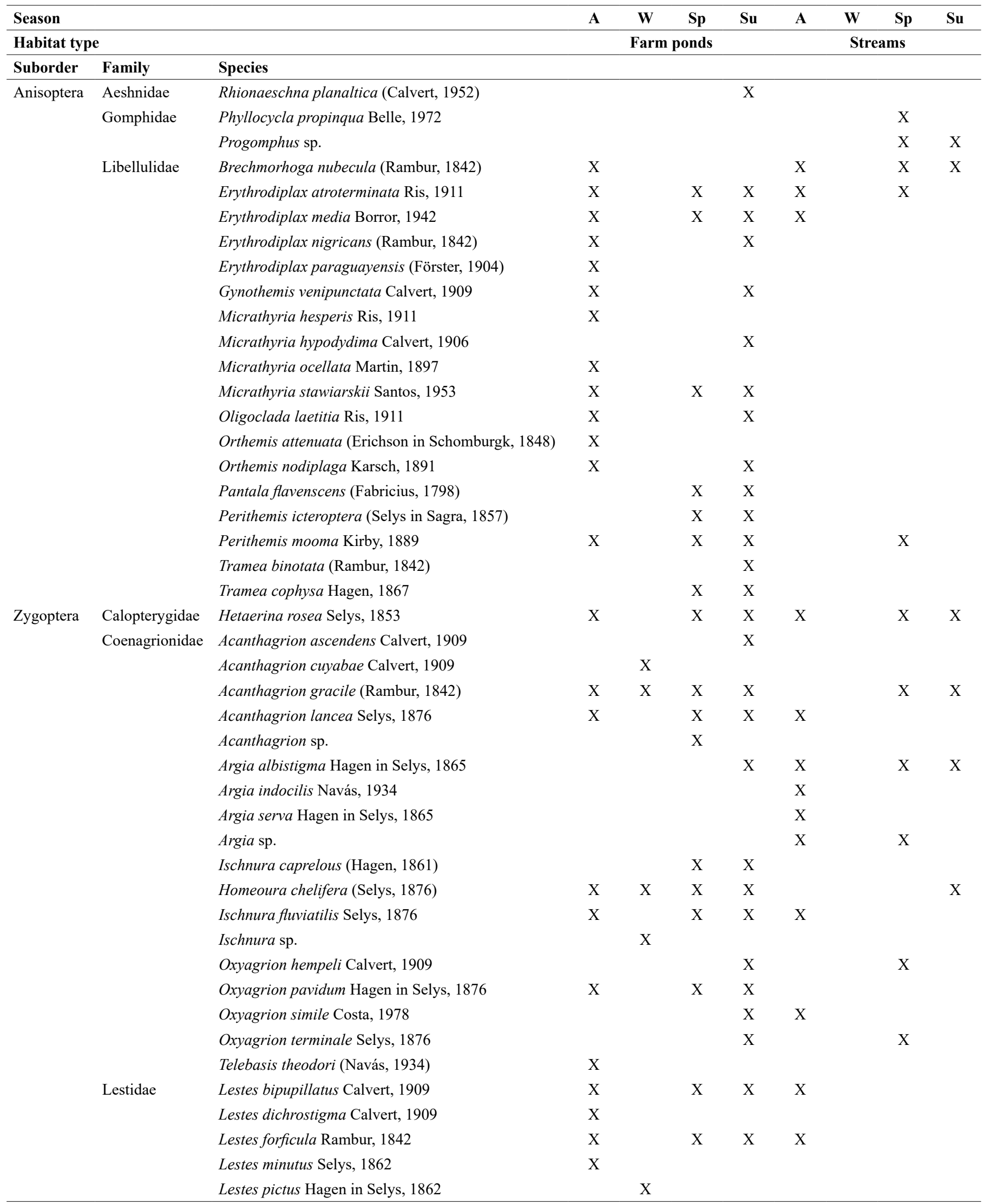


The dominant genera in the study area also followed previously observed patterns. Acanthagrion and Erythrodiplax are among the most speciose genera in the Neotropical Region (Kalkman et al. 2008), and they have been generally reported as the most species-rich genera in inventories through the Brazilian territory (Souza et al. 2013; Vilela et al. 2016; Koroiva et al. 2017). Lestes is a common genus in lentic habitats, and it was reported as one of the dominant taxa in ponds in several studies conducted in subtropical South America (Maltchik et al. 2010, Pires et al. 2013).

\section{New records}

\subsection{Argia serva Hagen in Selys, 1865 (Coenagrionidae)}

Argia serva (Coenagrionidae) is recorded for the first time in RS. Within the South American genus Argia Rambur, 1842, A. serva is the species with the southernmost distribution range, restricted to the Southern Cone (Palacio et al. 2018). Previous records of the species include Argentina (Lencioni 2006; Palacio et al. 2018), Uruguay (von Ellenrieder et al. 2009) and the state of Santa Catarina in southern Brazil (Lencioni 2006). In our study, the four other specimens collected were found in a stream (Lajeado da Gringa), in autumn (April). Finally, based on the latest compilation of odonate species for RS (Dalzochio et al. 2018), the record of $A$. serva in the study area elevates the number of species of Odonata in the state to 183.

\section{Checklist of Odonata in the Seasonal Deciduous Forest and preliminary comments on the role of phytoecological regions in the distribution of Odonata in $R S$}

The compilation of the species recorded in this study and the data from the literature indicate that $\sim 45 \%$ of the known odonate species in RS occur in the Seasonal Deciduous Forest in RS. In relation to the role of phytoecological regions in the distribution of Odonata in southern Brazil, and in spite of the contingencies associated with the early stages of this assessment, our study provides initial evidence that odonate composition does differ between phytoecological regions from the Atlantic Forest in RS (Table S1). In particular, the Seasonal Deciduous Forest and the Highland Grasslands share a low number of species and show elevated species turnover (Table S1). Odonate composition can be highly sensitive to landscape structure features (Kadoya et al. 2008, Brasil et al. 2018). The review by Paulson (2006) described that factors associated with forest structure (e.g., tree density) can explain the occurrence of many species. In fact, vegetation types in other biomes from southern Brazil have been found to support distinct compositions of Odonata. For instance, a recent study detected significant differences in the composition of Odonata among vegetation types in southern Brazil (ecoregions within the Pampa biome; Renner et al. 2019). In RS, the Seasonal Deciduous Forest encompasses dense forested habitats, while the Highland Grasslands are open-like landscapes, characterized by patches of Araucaria forests distributed in a grassland matrix. In addition, the Highland Grasslands are located in areas of higher altitude (up to $1000 \mathrm{~m}$ ) in RS (Oliveira-Filho \& Fontes 2000, Cordeiro \& Hasenack 2009, IBGE 2012), where temperature can reach low values. Previous studies showed that elevation gradients as well as forest and open landscapes can largely influence the regional richness and composition of Odonata (Novelo-Gutiérrez \& Gómez-Anaya 2009, Renner et al. 2019). In this sense, such environmental differences in vegetation type and elevation could have accounted for the differences in odonate composition here observed between the Seasonal Deciduous Forest and the Highland Grasslands.

\section{Odonate assemblages in farm ponds and streams}

Higher richness of Odonata was observed in lentic rather than lotic habitats, as shown in studies conducted in tropical (Cerrado biome: Vilela et al. 2016) and subtropical regions from Brazil, including studies with larval (Pires et al. 2013, 2014) and adult stages (Renner et al. 2016a, b). Odonate richness in lentic habitats is affected by several factors, such as the aquatic vegetation structure, which can provide perching and oviposition sites for adults (Kadoya et al. 2004, Remsburg \& Turner 2009). The aquatic vegetation structure also provides shelter and refuges from predators for the larval stages (Remsburg \& Turner 2009), allowing the development and completion of the life cycle and thus sustaining local populations. In this study, the farm ponds were largely covered by marginal and aquatic vegetation with different life forms along their perimeters (see original data in Pires et al. 2013; 2014), which likely provided suitable sites for the establishment of several species, thus increasing the richness in this habitat.

However, this pattern is not unequivocal in the literature. For instance, higher richness of Odonata was recorded in lotic rather than lentic habitats located in areas with intensive land use conversion, while the opposite pattern was observed in protected areas (Ferreira-Peruquetti \& Fonseca-Gessner 2010). Renner et al. (2018) also detected higher average local richness of Odonata in streams located in more pristine areas in the Pampa biome in RS than in man-made lakes surrounded by converted landscapes. This suggests that odonate richness in each habitat (lentic or lotic) could be dependent on the surrounding land use. In this study, the similar surrounding land use in the sampling sites as well as the relative preserved condition of the study area as a whole likely did not affect odonate local richness.

The composition and number of exclusive species also varied between farm ponds and streams, and the general pattern of distribution of families and species according to habitat types was similar to those previously mentioned in the literature. Four species were exclusively found in streams (Argia serva and Argia sp. (Coenagrionidae); Phyllocycla propinqua Belle, 1972 and Progomphus sp. (Gomphidae)). Coenagrionidae represented the richest family (11 species), followed by Libellulidae (five species). The predominance of these families in streams is analogous to data from the Cerrado biome (Vilela et al. 2016) as well as from tropical and subtropical areas of the Atlantic Forest biome (Assis et al. 2005; Renner et al. 2016a, b). In relation to species distribution, Gomphidae species were exclusively found in streams, as observed in previous studies conducted in tropical regions from Brazil (Carvalho \& Nessimian 2002, Assis et al. 2005). Additionally, larvae of most genera from this family were detected solely in streams in the study area (Pires et al. 2013). Argia, a typical dweller of streams (Lencioni 2006), was the richest genus in this habitat. In this study, although adults of some species of Argia were observed flying around farm ponds, their larvae were not found in lentic habitats (Pires et al. 2013). Similarly, Calopterygidae species were detected as adults in both habitats, although their larvae were exclusively found in lotic habitats, in accordance with the findings of previous studies (Carvalho \& Nessimian 2002; Pires et al. 2013). 
In farm ponds, all species of Libellulidae, which was the most diverse family in the study area (44.8\% of the total), occurred exclusively in this habitat. Coenagrionidae species corresponded to $35.5 \%$ of the total number of species detected in farm ponds (16). In addition, all species of Acanthagrion, Lestes (five species each) and Oxyagrion (four species) occurred in farm ponds only (Table 2). Despite the predominance of several species of Acanthagrion, Oxyagrion and Erythrodiplax in farm ponds, as observed in other studies (Renner, Perico, et al. 2016, Renner, Périco, et al. 2016), Micrathyria was the richest genus (five species, along with Lestes) in this habitat. However, this result should not be considered surprising, as individuals of Micrathyria commonly occur in lentic ecosystems, both in larval and adult stages (Garrison et al. 2006). Larvae of this genus also predominated in farm ponds in the study area (Pires et al. 2013, 2014). In addition, 30 species were exclusive of farm ponds (Table 2). The higher number of exclusive species in farm ponds was also detected in other regions of southern Brazil (Renner et al. 2016b). Previous reviews showed that man-made farm ponds can increase the regional pool of species richness, mostly by acting as an additional habitat for generalist species (Ruggiero et al. 2008). In spite of the increase in the taxonomic richness, some authors detected that in a landscape context, the predominance of generalist species could potentially lead to communities more functionally homogenous (Olden 2006; DeVictor et al. 2008). Although studies on the functional structure of odonates in farm ponds are lacking to our knowledge, this could also potentially apply to the case of odonate communities in farm ponds.

\section{Comments on the seasonal distribution and life cycles of species of Odonata in the study area}

Previous data on the temporal distribution of larval assemblages of Odonata in farm ponds from the study area (Pires et al. 2014) showed that abundance peaked in spring (from September to November), suggesting that eggs hatched from spring on (after temperature warming). Taking into account larval growth periods and posterior emergence, the detected pattern for larvae could be related to the highest number of adult species observed in the present study between summer and autumn. Synchronized emergence of odonate adults in warmer periods has been also described in species-specific studies conducted in Argentina (Muzón et al. 1990, Capítulo 2000). In this context, our results suggest the completion of one generation in farm ponds, which is supported by the detection of $70 \%$ of the species recorded in farm ponds $(\mathrm{N}=28)$ in one or two consecutive seasons, mostly summer and autumn. In fact, few species $(\mathrm{N}=10 ; 25 \%)$ were detected in three seasons. Acanthagrion gracile and Homeoura chelifera were the sole species occurring throughout all seasons in farm ponds. This result loosely suggests that species from these genera were able to complete more than one generation per year, as previously detected in other studies (von Ellenrieder 2000).

Corbet et al. (2006) stressed that most odonates inhabiting perennial streams tend to show slow life cycles, producing one or less generations per year. To our knowledge, no study has yet attempted at assessing the life cycle of odonates in subtropical Brazilian streams. Our results suggest a similar pattern, as the complete absence of odonates in winter and the elevated number of species $(\mathrm{N}=13 ; 65 \%)$ that were solely detected in one season (mostly non-consecutive - spring and autumn).
In this context, our results are generally in accordance with the review on voltinism of Odonata by Corbet et al. (2006), which described that most species in subtropical regions show at least one generation per year.

All results combined, they indicate a strong seasonal pattern in the activity of adult odonate species in the study area. Several studies showed that the life cycle of Odonata is limited by the seasonality of climatic conditions. In this study, the colder temperatures and reduced photoperiod typical of the winter should have played a stronger role in this result. Temperature strongly drives egg development rates, influencing the synchronized emergence of adult odonates, as well as their activity patterns (Corbet 2004). However, our results are in opposition to studies on tropical regions of Brazil, which suggested the role of wet and dry seasons on seasonal occurrence of adults (Franco \& Takeda 2002, Vilela et al. 2016). One of the characteristics of the temperate humid climate in RS is the absence of a marked dry season (Maluf 2000), and thus adult activity was more likely to be associated with temperature rather than rainfall in the region.

\section{Final remarks}

Our study showed that the middle course of the Jacuí River basin harbors a significant part (potentially up to one third) of the known species diversity of Odonata of the state of Rio Grande do Sul. The range of habitat types assessed likely accounted for the elevated richness, as odonate composition differed between farm ponds and streams. The widespread distribution of farm ponds harboring high local richness of Odonata (as well as an elevated number of exclusive taxa) contributed to the high diversity observed in the study area, reinforcing the role of man-made habitats in affecting spatial patterns of freshwater diversity. In addition, our results are also likely related to the well-preserved environmental conditions and historic land use of the landscape in the study area. The high declivity of the study area hinders the conversion of large areas for anthropic land uses, contributing for the existence of relatively large fragments of preserved and/or secondary-growth forests in this region (Marcuzzo et al. 1998). This context contrasts with the remnants of the other phytoecological regions of the Atlantic Forest in the state, which have been largely converted (Cordeiro \& Hasenack 2009).

Our results also represented the first attempt to highlight the role of the phytoecological regions in the distribution of Odonata in southern Brazil. The compilation of our results and of data from the literature showed that the Seasonal Deciduous Forest supports a large part of the known diversity of Odonata in RS. In a broader perspective, our results reinforce the need of conservation programs in the Atlantic Forest biome, as currently only $\sim 7.5 \%$ of the original area of this biome is represented in Rio Grande do Sul (Rio Grande do Sul 2019). Finally, our study also provided information on the life cycle of Odonata species in a subtropical region from Brazil. In this sense, marked seasonal fluctuations in the occurrence of adult odonates were detected in the study area. Most species occurred from summer to autumn and were absent in the winter, suggesting a low number of generations. These results likely suggest a strong role of the seasonal variations in temperature and photoperiod, typical of subtropical climate, in the life cycle of Odonata in southern Brazil. 


\section{Suplementary material}

The following online material is available for this article:

Figure S1 - Occurrence records of odonate species within the original area of Seasonal Deciduous Forest in the state of Rio Grande do Sul.

Table S1 - List of odonate species occurring in areas of Seasonal Deciduous Forests in the state of Rio Grande do Sul, Brazil.

\section{Author Contributions}

Mateus Marques Pires: contribution to data collection, species identification, data analysis and interpretation, drafting and intellectual content of the manuscript.

Carla Bender Kotzian: contribution to project conception, data collection and interpretation; contribution to critical revision and intellectual content of the manuscript.

Cleber Sganzerla and Marina Schmidt Dalzochio: contribution to species identification and drafting of the manuscript.

Gabriel Prass: contribution to species identification.

Eduardo Périco: contribution to critical revision and intellectual content of the manuscript.

\section{Conflicts of interest}

The authors declare that they have no conflict of interest related to the publication of this manuscript.

\section{References}

ANJOS-SANTOS, D. \& COSTA, J.M. 2006. A revised checklist of Odonata (Insecta) from Marambaia, Rio de Janeiro, Brazil with eight new records. Zootaxa 50(1300):37-50.

ASSIS, J.C.F. de, CARVALHO, A.L. \& NESSIMIAN, J.L. 2005. Composição e preferência por microhábitat de imaturos de Odonata (Insecta) em um trecho de baixada do Rio Ubatiba, Maricá-RJ, Brasil. Rev. Bras. Entomol. 48(2):273-282.

BARBOSA, M.S., BORGES, L.R., DIOGO, D.S., VENÂNCIO, H., \& SANTOS, J.C. 2019. Odonate Communities of the Sucupira Reservoir, Rio Uberabinha, Minas Gerais, Brazil. Pap. Avulsos Zool. 59:e20195922.

BORGES, L.R., BARBOSA, M.S., CARNEIRO, M.A.A., VILELA, D.S., \& SANTOS, J.C. 2019. Dragonflies and damselflies (Insecta: Odonata) from a Cerrado area at Triângulo Mineiro, Minas Gerais, Brazil. Biota Neotropica. 19(1):e20180609. http://dx.doi.org/10.1590/1676-0611-bn-2018-0609 (last access on 25/06/2019)

BRASIL, L.S., OLIVEIRA-JÚNIOR, J.M., CALVÃO, L.B., CARVALHO, F.G., MONTEIRO-JÚNIOR, C.S., DIAS-SILVA, K. \& JUEN, L. 2018. Spatial, biogeographic and environmental predictors of diversity in Amazonian Zygoptera. Insect Conserv. Divers. 11(2):174-184.

CAPÍTULO, A.R. 2000. Population dynamics of larval stages of Tauriphila risi Martin and Erythemis attala (Selys) Argentina (Anisoptera: Libellulidae). Odonatologica 29(346):333-340.

CARVALHO, A.L. \& NESSIMIAN, J.L. 2002. Odonata do Estado do Rio de Janeiro, brasil: hábitats e hábitos das larvas. In Ecologia de Insetos Aquáticos (A.L. Carvalho \& J.L. Nessimian, eds). PPGE-UFRJ, Rio de Janeiro, p.3-28.

CONSATTI, G., SANTOS, D.M., RENNER, S. \& PÉRICO, E. 2014. Presença de Odonata em áreas preservadas e não preservadas nas matas ciliares do Rio Taquari, RS. Rev. Iniciação Científica da ULBRA 12:57-65.
CORBET, P.S. 2004. Dragonflies: Behaviour and Ecology of Odonata. 2 ed. Harley Books, Colchester.

CORBET, P.S., SUHLING, F. \& SOENDGERATH, D. 2006. Voltinism of Odonata: a review. Int. J. Odonatol. 9(1):1-44.

CORDEIRO, J.L.P. \& HASENACK, H. 2009. Cobertura vegetal atual do Rio Grande do Sul. In Campos Sulinos: conservação e uso sustentável da biodiversidade (V.D.P. Pillar, ed.). Ministério do Meio Ambiente, Brasília, p.285-299.

CÓRDOBA-AGUILAR, A. 2008. Dragonflies \& Damselflies: Model Organisms for Ecological and Evolutionary Research. Oxford University Press, New York.

DALZOCHIO, M.S., RENNER, S., SGANZERLA, C., PRASS, G., ELY, G.J., SALVI, L.C., DAMETTO, N. \& PÉRICO, E. 2018. Checklist of Odonata (Insecta) in the state of Rio Grande do Sul, Brazil with seven new records. Biota Neotropica. 18(4):e20180551. htp://dx.doi.org/10.1590/1676-0611bn-2018-0551 (last access on 15/04/2019)

DE MARCO, P., NOGUEIRA, D.S., CORREA, C.C., VIEIRA, T.B., SILVA, K.D., PINTO, N.S., BICHSEL, D., HIROTA, A.S.V., VIEIRA, R.R.S., CARNEIRO, F.M., DE OLIVEIRA, A.A.B., CARVALHO, P., BASTOS, R.P., ILG, C. \& OERTLI, B. 2014. Patterns in the organization of Cerrado pond biodiversity in Brazilian pasture landscapes. Hydrobiologia 723(1):87-101.

DE MARCO, P. \& VIANNA, D.M. 2005. Distribuição do esforço de coleta de Odonata no Brasil - Subsídios para escolha de áreas prioritárias para levantamentos faunísticos. Lundiana 6:13-26.

DEVICTOR, V., JULLIARD, R. \& JIGUET, F. 2008. Distribution of specialist and generalist species along spatial gradients of habitat disturbance and fragmentation. Oikos 117(4):507-514.

DURLO, M.A., MARCHIORI, J.N.C. \& LONGHI, S.J. 1982. Composição e estrutura da mata secundária no vale do rio Jacuí, RS. Ciência e Natura. 4:129-139.

FERREIRA-PERUQUETTI, P.S. \& FONSECA-GESSNER, A. 2010. Comunidade de Odonata (Insecta) em áreas naturais de Cerrado e monocultura no nordeste do Estado de São Paulo: relação entre o uso do solo e a riqueza faunística. Rev. Bras. Zool. 20(2):219-224.

FERRO, V.G. \& TESTON, J.A. 2009. Composição de espécies de Arctiidae (Lepidoptera) no sul do Brasil: relação entre tipos de vegetação e entre a configuração espacial do hábitat. Rev. Bras. Entomol. 53(2):278-286.

FRANCO, G.M.S. \& TAKEDA, A.M. 2002. Spatial Spatial and temporal variation of Odonata larvae associated with macrophytes in two floodplain lakes from the upper Paraná River, Brazil. Acta Sci. 24(2):345-351.

GARRISON, R.W., ELLENRIEDER, N. von \& LOUTON, J.A. 2006. Dragonfly Genera of the New World: an illustrated and annotated key to the Anisoptera. The Johns Hopkins University Press, Baltimore.

GOTELLI, N.J. \& COLWELL, R.K. 2001. Quantifyinf Biodiversity: Procedures and Pitfalls in the Measurement and Comparison of Species Richness. Ecol. Lett. 4(4):379-391.

HANAUER, G. \& RENNER, S. 2008. Inventariamento preliminar da fauna de libélulas (odonata) em quatro municípios do Vale do Taquari/RS. Rev. Destaques Acad. 6(3):36-45.

IBGE. 2004. Mapa de Biomas do Brasil. Primeira Aproximação. Escala 1:5.000.000

IBGE. 2012. Manual Técnico da Vegetação Brasileira. 2 ed. IBGE, Rio de Janeiro.

ISERHARD, C.A., ROMANOWSKI, H.P., RICHTER, A. \& DE SOUZA MENDONÇA, M. 2017. Monitoring temporal variation to assess changes in the structure of subtropical Atlantic forest butterfly communities. Environ. Entomol. 46(4):804-813

JUEN, L. \& DE MARCO, P. 2012. Dragonfly endemism in the Brazilian Amazon: Competing hypotheses for biogeographical patterns. Biodivers. Conserv. 21(13):3507-3521 
JUEN, L., OLIVEIRA-JUNIOR, J.M.B. de, SHIMANO, Y., MENDES, T.P. \& CABETTE, H.S.R. 2014. Composição e riqueza de Odonata (Insecta) em riachos com diferentes níveis de conservação em um ecótone CerradoFloresta Amazônica. Acta Amaz. 44(2):223-233.

KADOYA, T., SUDA, S.I., TSUBAKI, Y. \& WASHITANI, I. 2008. The sensitivity of dragonflies to landscape structure differs between life-history groups. Landsc. Ecol. 23(2):149-158.

KADOYA, T., SUDA, S.I. \& WASHITANI, I. 2004. Dragonfly species richness on man-made ponds: Effects of pond size and pond age on newly established assemblages. Ecol. Res. 19(5):461-467.

KALKMAN, V.J., CLAUSNITZER, V., DIJKSTRA, K.D.B., ORR, A.G., PAULSON, D.R. \& VAN TOL, J. 2008. Global diversity of dragonflies (Odonata) in freshwater. Hydrobiologia 595(1):351-363.

KITTEL, R.N. \& ENGELS, W. 2014. Diversity of damselflies (Odonata: Zygoptera ) of the state Rio Grande do Sul, Brazil, with four new records for the state. Not. Odonatol. 8(3):49-55.

KITTEL, R.N. \& ENGELS, W. 2016. Diversity of dragonflies (Odonata: Anisoptera) of Rio Grande do Sul, Brazil, with five new records for the state. Not. Odonatol. 8(8):284-289.

KOROIVA, R., RODRIGUES, M.E., VALENTE-NETO, F. \& ROQUE, F. de O. 2017. Odonates from Bodoquena Plateau: checklist and information about endangered species. Biota Neotropica. 17(3):e20160310. http://10.1590/1676-0611-bn-2016-0310 (last access on 15/04/2019)

LENCIONI, F.A.A. 2005. Damselflies of Brazil: an illustrated identification guide. I - Non-Coenagrionidae families. All Print, São Paulo.

LENCIONI, F.A.A. 2006. Damselflies of Brazil: an illustrated identification guide. II - Coenagrionidae. All Print, São Paulo.

MALTCHIK, L., STENERT, C., KOTZIAN, C.B. \& PIRES, M.M. 2010. Responses of Odonate Communities to Environmental Factors in Southern Brazil Wetlands. J. Kansas Entomol. Soc. 83(3):208-220.

MALUF, J.R.T. 2000. Nova classificação climática do Estado do Rio Grande do Sul A new climatic classification for the State of Rio Grande do Sul, Brazil. Rev. Bras. Agrometeorol. 8(1):141-150.

MARCUZZO, S., PAGEL, S.M. \& CHIAPPETTI, M.I.S. 1998. A reserva de biosfera da Mata Atlântica do Rio Grande do Sul. Cad. n. 11. CETESB, São Paulo.

MITTERMEIER, R.A., TURNER, W.R., LARSEN, F.W., BROOKS, T.M. \& GASCON, C. 2011. Global biodiversity conservation: the critical role of hotspots. In Biodiversity hotspots (F.E. Zachos \& J.C. Habel, eds). Springer, Berlin, p.3-22.

MUZÓN, J., RODRIGUES-CAPÍTULO, A. \& JURZITZA, G. 1990. Populationsdynamik von Telebasis willinki Fraser, 1948 im Galeriewald des Río de La Plata bei Punta Lara, Argentinien (Odonata: Coenagrionidae). Opusc. Zool. Flum. 53:1-10.

NÓBREGA, C.C. \& DE MARCO, P. 2011. Unprotecting the rare species: A niche-based gap analysis for odonates in a core Cerrado area. Divers. Distrib. 17(3):491-505.

NOVELO-GUTIÉRREZ, R. \& GÓMEZ-ANAYA, J.A. 2009. A comparative study of Odonata (Insecta) assemblages along an altitudinal gradient in the sierra de Coalcomán Mountains, Michoacán, Mexico. Biodivers. Conserv. 18(3):679-698.

OKSANEN, J., BLANCHET, F.G., FRIENDLY, M., KINDT, R., LEGENDRE, P., MCGLINN, D., MINCHIN, P.R., O'HARA, R.B., SIMPSON, G.L., SOLYMOS, P., STEVENS, M.H.H., SZOECS, E. \& WAGNER, H. 2018. vegan: Community Ecology Package.

OLDEN, J. D. 2006. Biotic homogenization: a new research agenda for conservation biogeography. J. Biogeogr. 33:2027-2039.

OLIVEIRA-FILHO, A.T. \& FONTES, M.A.L. 2000. Patterns of Floristic Differentiation among Atlantic Forests in Southeastern Brazil and the Influence of Climate1. Biotropica 32(4):793.
PALACIO, A. Del, LOZANO, F. \& MUZÓN, J. 2018. Description of the final instar larva of argia serva hagein selys, 1865 (Odonata coenagrionidae). An. Acad. Bras. Cienc. 90(3):3017-3022.

PAULSON, D. 2006. The importance of forests to Neotropical dragonflies. In Fourth WDA International Symposium of Odonatology (A. Cordero-Rivera, ed.). Pensoft, Pontevedra, p.79-101.

PEREIRA, P.R.B., NETTO, L.R.G., BORIN, C.J.A. \& SARTORI, M.G.B. 1989. Contribuição à geografia física do município de Santa Maria: unidades de paisagem. Geogr. Ensino e Pesqui. 3(1):37-68.

PINTO, A.P. 2019. Odonata in Catálogo Taxonômico da Fauna do Brasil. PNUD. Available in: <http://fauna.jbrj.gov.br/fauna/faunadobrasil/171> Last access on: 7 Abr. 2019

PIRES, M.M., KOTZIAN, C.B. \& SPIES, M.R. 2014. Diversity and Spatiotemporal Distribution of Larval Odonate Assemblages in Temperate Neotropical Farm Ponds. J. Insect Sci. 14(275):.

PIRES, M.M., KOTZIAN, C.B., SPIES, M.R. \& NERI, D.B. 2013. Diversity of Odonata (Insecta) larvae in streams and farm ponds of a montane region in southern Brazil. Biota Neotrop. 13(3):259-267. http://dx.doi.org/10.1590/ S1676-060320130003000300028 (last access on 15/04/2019)

R CORE TEAM. 2018. R: A Language and Environment for Statistical Computing.

REMSBURG, A.J. \& TURNER, M.G. 2009. Aquatic and terrestrial drivers of dragonfly (Odonata) assemblages within and among north-temperate lakes. J. North Am. Benthol. Soc. 28(1):44-56.

RENNER, S., PÉRICO, E., DALZOCHIO, M.S. \& SAHLÉN, G. 2019. Ecoregions within the Brazilian Pampa biome reflected in Odonata species assemblies. Austral Ecol. 44(3):461-427.

RENNER, S., PÉRICO, E., DALZOCHIO, M.S. \& SAHLÉN, G. 2018. Water body type and land cover shape the dragonfly communities (Odonata) in the Pampa biome, Rio Grande do Sul, Brazil. J. Insect Conserv. 22(1):113-125.

RENNER, S., PÉRICO, E., ELY, G.J. \& SAHLÉN, G. 2017. Preliminary dragonfly (Odonata) species list from the Pampa biome in Rio Grande do Sul, Brazil, with ecological notes for 19 new records for the State. Biota Neotropica. 17(4):e20170374. http://dx.doi.org/10.1590/1676-0611bn-2017-0374 (last acess on 15/04/2019)

RENNER, S., PERICO, E. \& SAHLÉN, G. 2013. Dragonflies (Odonata) in Subtropical Atlantic Forest fragments in Rio Grande do Sul, Brazil: seasonal diversity and composition. Sci. Plena 9(1):1-8.

RENNER, S., PERICO, E. \& SAHLEN, G. 2016a. Man-made lakes form speciesrich dragonfly communities in the Brazilian Atlantic Forest (Odonata). Odonatologica 45(3-4):135-154.

RENNER, S., PÉRICO, E., SAHLÉN, G. 2016b. List of Odonates from the Floresta Nacional de São Francisco de Paula (FLONA - SFP), with two new distribution records for Rio Grande do Sul, Brazil. Biota Neotropica. 16(3):e20150132. http://dx.doi.org/10.1590/1676-0611-BN-2015-0132 (last access on 15/04/2019)

RENNER, S., PÉRICO, E., SAHLÉN, G., DOS SANTOS, D.M. \& CONSATTI, G. 2015. Dragonflies (Odonata) from the Taquari River valley region, Rio Grande do Sul, Brazil. Check List 11(5):1740.

RIO GRANDE DO SUL. 2019. Atlas Socioeconômico do RS. 4 ed. Secretaria de Planejamento, Gestão e Participação Cidadã, Porto Alegre.

RUGgiero, A., CÉRÉGHino, R., FIGUEROLA, J., MARTY, P. \& ANGÉLIBERT, S. 2008. Farm ponds make a contribution to the biodiversity of aquatic insects in a French agricultural landscape. Comptes Rendus - Biol. 331(4):298-308.

SCHORR, M. \& PAULSON, D. 2019. World Odonata List. Electron. Database Access. http://www.pugetsound.edu/academics/academic-resources/slatermuseum/biodiversity-resouces/dragonflies/world-odonata-list2/. Last access on: 7 Abr. 2019. 
Pires, M.M. et al.

SIEWERT, R.R., ISERHARD, C.A., ROMANOWSKI, H.P., CALLAGHAN, C.J. \& MOSER, A. 2014. Distribution patterns of riodinid butterflies (Lepidoptera: Riodinidae) from southern Brazil. Zool. Stud. 53(1):1-10.

SOUZA, M.M. de, SOUZA, B., PEREIRA, M.C.S. de A. \& MACHADO, A.B.M. 2013. List of odonates from Mata do Baú, Barroso, Minas Gerais, Brazil. Check List 9(6):1367-1370.

VILELA, D.S., FERREIRA, R.G. \& DEL-CLARO, K. 2016. A comunidade de odonatos de uma vereda Brasileira: Padrões sazonais, diversidade de espécies e raridade em um ambiente de buritizal. Biosci. J. 32(2):486-495.

VON ELLENRIEDER, N. 2000. Species composition and temporal variation of odonate assemblages in the subtropical-pampasic ecotone, Buenos Aires, Argentina. Odonatologica 29(1):17-30.
VON ELLENRIEDER, N. 2009. Databasing dragonflies: state of knowledge in the Neotropical region. Agrion 13(2):58-72.

VON ELLENRIEDER, N., MOLINERI, C. \& EMMERICH, D. 2009. Odonata de Uruguay: lista de especies y nuevos registros. Rev. Soc. Entomol. Arg. 68(1-2):227-230.

ZAMANILLO, E.A., TUCCI, C.E.M., SIMÕES LOPES, M.O. \& LANNA, A.E. 1989. Management of navigation in the Jacuí River. Water Int. 14(4):181-192.

Received: $15 / 04 / 2019$

Revised: 25/06/2019

Accepted: 04/07/2019

Published online: 26/08/2019 